\title{
Correlation between ribosomal DNA polymorphism and electrophoretic enzyme polymorphism in Yersinia
}

\author{
Nicole Picard-Pasquier, ${ }^{1}$ Bertrand Picard, ${ }^{2}$ Sarita Heeralal, ${ }^{1}$ \\ Rajagopal Krishnamoorthy ${ }^{1}$ and PhilipPe Goullet ${ }^{2 *}$ \\ ${ }^{1}$ Institut de Pathologie Moléculaire, Unité 15 de l'Institut National de la Santé et de la Recherche Médicale, \\ 24 rue du Faubourg Saint Jacques, 75674 Paris cedex 14, France \\ ${ }^{2}$ Laboratoire de Microbiologie, Faculté de Médecine Xavier Bichat (Université Paris VII), 16 rue Henri Huchard, \\ 75018 Paris, France
}

(Received 28 November 1989; revised 19 March 1990; accepted 2 April 1990)

\begin{abstract}
Ribosomal DNA (rDNA) polymorphism was compared with electrophoretic enzyme polymorphism for the intraand interspecies differentiation of Yersinia enterocolitica, $Y$. pseudotuberculosis, $Y$. intermedia, $Y$. aldovae, $Y$. frederiksenii and $Y$. kristensenii. DNA from 90 strains previously classified into six zymotypes (Y. enterocolitica and $Y$. frederiksenii) and into distinct enzyme electrophoretic patterns (the four other species) was digested with EcoRI or HindIII and analysed by Southern blotting. The six species were clearly differentiated from each other. In $Y$. enterocolitica, the subclassification of biotype 1 into zymotypes $1 \mathrm{~A}$ and $1 B$ was also reflected in the rDNA and the four other bio-zymotypes gave four different classes of restriction pattern. In Y. frederiksenii, both EcoRI and HindIII gave five distinct riboclasses which correlated with the zymotypes. In the four other species, the phenotype polymorphism appeared to be better correlated with the restriction fragment length polymorphism data in some enzymes than others. The data demonstrate that the inter- and intraspecies classification by rDNA polymorphism using two restriction enzymes is similar to that based on electrophoretic enzyme polymorphism. The analysis could be refined for taxonomic and epidemiological purposes by using other restriction enzymes.
\end{abstract}

\section{Introduction}

The genetic diversity of bacterial species can be studied either by electrophoretic polymorphism of enzymes or directly by analysing chromosomal DNA polymorphism. Differential melting profiles of total DNA hybridized to a reference DNA have given information on the overall genetic, relatedness of bacterial species, but this approach is inappropriate for establishing genetic relationships among closely related organisms. The restriction patterns of DNA, visualized by ethidium bromide staining, have been used as taxonomic or epidemiological markers for Leptospira (Marshall et al., 1984), Chlamydia (McClenaghan et al., 1984), Campylobacter (Kakoyiannis et al., 1984), Neisseria meningitidis (Kristiansen et al., 1984) and Branhamella catharralis (Patterson et al., 1988). However, the complexity of the large number of

Abbreviations: GDH, glutamate dehydrogenase; $\mathrm{MDH}$, malate dehydrogenase; $\mathrm{RBR}$, relative binding ratio; RFLP, restriction fragment length polymorphism; $\boldsymbol{M}_{\boldsymbol{F}}$, electrophoretic mobility. fragments obtained with commonly used restriction enzymes made a rigorous side-by-side comparison of the stained patterns mandatory in order to understand the DNA relationships. Some authors (Allardet-Servent $e t$ al., 1988; Schwartz \& Cantor, 1984) used low-cleavage frequency restriction enzymes to circumvent this problem, but the resulting detectable DNA polymorphism is naturally low and makes the technique less useful for studies of intraspecies differences.

The optimal situation would be to use the common restriction enzymes combined with selective visualization of a reasonable number of polymorphic fragments. Grimont \& Grimont (1986) and others (Bercovier et al., 1986; Magee et al., 1987; Irino et al., 1988; Kuijper et al., 1989; Stull et al., 1988; Yogev et al., 1988) have demonstrated that the restriction fragment length polymorphism (RFLP) of ribosomal DNA (rDNA) may be a useful genetic marker for species and subspecies classification.

In previous papers (Goullet \& Picard, 1984, 1988), we have analysed the enzyme polymorphism of Yersinia 
enterocolitica, $Y$. pseudotuberculosis, $Y$. intermedia, $Y$. aldovae, $Y$. frederiksenii and $Y$. kristensenii and demonstrated that the 192 strains studied may be identified at the species level by their enzymic electrophoretograms. Within $Y$. enterocolitica, biotype 1 was divided into two zymotypes (1A and 1B), while the four other biotypes corresponded to four different zymotypes. In the absence of an intraspecies classification by biotype, we have delineated six zymotypes in $Y$. frederiksenii. The subgrouping of the electrophoretic patterns into zymotype appeared to be less convincing for the four other species.

The aim of the present work was to evaluate the potential of ribotyping technology for the inter- and intraspecies classification of Yersinia and to compare the results with those obtained by enzyme electrophoretic polymorphism. To this end, we studied 90 Yersinia strains belonging to the above six species. The strains were chosen for their distinct enzyme electrophoretic pattern.

\section{Methods}

Bacterial strains. The 90 Yersinia strains tested had been previously analysed for their enzyme polymorphism (Goullet \& Picard, 1984, 1988) (Table 1).

RFLP of $r D N A$. The original method described by Grimont \& Grimont (1986) was modified to streamline the entire procedure
(Picard-Pasquier et al., 1989). For preparation of DNA, bacteria from a $10 \mathrm{ml}$ overnight culture at $28^{\circ} \mathrm{C}$ were harvested by centrifugation at $4000 \mathrm{~g}$ for $5 \mathrm{~min}$ at $4{ }^{\circ} \mathrm{C}$ and washed with $300 \mu \mathrm{l} 50 \mathrm{~mm}-\mathrm{Tris} / \mathrm{HCl}, \mathrm{pH} 8$, $1 \mathrm{~mm}$-EDTA. The washed pellet was resuspended in $300 \mu \mathrm{l}, 50 \mathrm{~mm}-$ Tris $/ \mathrm{HCl}, \mathrm{pH} 8,25 \%(\mathrm{w} / \mathrm{v})$ sucrose, to which were added $200 \mu \mathrm{l}$ lysozyme $\left(300 \mu \mathrm{g} \mathrm{ml}^{-1}\right)$ and $120 \mu 10.5 \mathrm{M}$-EDTA, $\mathrm{pH}$ 8. The suspension was mixed and allowed to stand on ice for $5 \mathrm{~min}$. The cells were lysed by adding $1.4 \mathrm{ml} 6 \mathrm{M}$-guanidium chloride followed by $100 \mu 17.5 \mathrm{M}$ ammonium acetate and incubating at room temperature with agitation for $1 \mathrm{~h}$. Proteins were digested with $15 \mu \mathrm{l}$ proteinase $\mathrm{K}\left(10 \mathrm{mg} \mathrm{ml}^{-1}\right)$ plus $200 \mu \mathrm{l} 10 \%$ (w/v) Sarkosyl for $60 \mathrm{~min}$ at $60^{\circ} \mathrm{C}$. High molecular mass DNA was precipitated with 2 vols $100 \%$ ice-cold ethanol and recovered by spooling. The DNA was resuspended in $6 \mathrm{mM}-\mathrm{Tris} / \mathrm{HCl}$, pH 7.5, $6 \mathrm{mM}-\mathrm{NaCl}, 0 \cdot 1 \mathrm{~mm}$-EDTA. DNA $(1-5 \mu \mathrm{g})$ was digested with EcoRI or HindIII, size-separated by electrophoresis on submarine agarose gels $(0.8 \%)$ for $3 \mathrm{~h}$ at $1.5 \mathrm{~V} \mathrm{~cm}^{-1}$ and transferred to nylon membranes (GeneScreen Plus) by the procedure of Southern (1975) for $18 \mathrm{~h}$. rRNA ( $250 \mathrm{ng}$ of $16 \mathrm{~S}$ and 23S RNA from E. coli, Boehringer) was labelled to high specific activity $\left(6 \times 10^{7}\right.$ d.p.m. $)$ by a random oligopriming technique using a mixture of hexanucleotides (Pharmacia) and cloned reverse transcriptase from M-MLV (BRL) according to the manufacturer's instructions in the presence of $\left[{ }^{32} \mathrm{P}\right] \mathrm{dCTP}[800 \mathrm{Ci}$ $\mathrm{mmol}^{-1}$ (29.6 TBq mmol ${ }^{-1}$ ) Amersham]. Cold template RNA was destroyed by boiling with $2 \mathrm{M}-\mathrm{NaOH}, 10 \%$ (w/v) SDS for $10 \mathrm{~min}$ and the labelled rDNA fragments were purified by column chromatography on Sephadex G-50. The DNA was hybridized according to the membrane manufacturer's instructions (final composition of the hybridization solution $50 \mathrm{~mm}-\mathrm{Tris} / \mathrm{HCl}, \mathrm{pH} 7.5,1 \mathrm{~m}-\mathrm{NaCl}, 1 \%$, w/v, SDS, $10 \%$, w/v, dextran sulphate) for $3 \mathrm{~h}$ at $65^{\circ} \mathrm{C}$ and the filters were washed twice with $0.15 \mathrm{M}-\mathrm{NaCl}, 0.015 \mathrm{M}$-sodium citrate (SSC), $\mathrm{pH} 7.3$, containing $0.1 \% \mathrm{SDS}$ for $15 \mathrm{~min}$ at room temperature. The filters were autoradiographed by exposure to Hyper-film MP (Amersham) for $30 \mathrm{~min}$ at room temperature.

Table 1. Strains examined

\begin{tabular}{|c|c|c|c|c|}
\hline $\begin{array}{l}\text { Laboratory } \\
\text { code }\end{array}$ & $\begin{array}{c}\text { Strain } \\
\text { designation* }\end{array}$ & Biotype & Zymotype & $\begin{array}{l}\text { Main enzyme } \\
\text { electrophoretic } \\
\text { results of the } \\
\text { intraspecies } \\
\text { characterization } \\
\text { correlating } \\
\text { with the RFLP data }\end{array}$ \\
\hline \multicolumn{5}{|c|}{ Yersinia enterocolitica } \\
\hline $\begin{array}{l}1 \\
2 \\
3 \\
4 \\
5\end{array}$ & $\begin{array}{lr}\text { CNY } & 96 \\
\text { CNY } & 846 \\
\text { CNY } & 161 \\
\text { CNY } & 3419 \\
\text { CNY } & 10389\end{array}$ & $\begin{array}{l}1 \\
1 \\
1 \\
1 \\
1\end{array}$ & $\begin{array}{l}1 \mathrm{~A} \\
1 \mathrm{~A} \\
1 \mathrm{~A} \\
1 \mathrm{~A} \\
1 \mathrm{~A}\end{array}$ & $\begin{array}{l}\text { Esterase } \mathrm{E}_{2} \text { at } M_{F} 65 \\
\text { Esterase } \mathrm{E}_{3} \text { at } M_{F} 55 \\
\text { Esterase } \mathrm{E}_{4} \text { at } M_{F} 48 \\
\text { Esterase } \mathrm{E}_{5} \text { at } M_{F} 20 \\
\text { Esterase } \mathrm{E}_{6} \text { at } M_{F}-7\end{array}$ \\
\hline $\begin{array}{l}6 \\
7 \\
8\end{array}$ & $\begin{array}{lr}\text { CNY } & 9023 \\
\text { CNY } & 3865 \\
\text { CNY } & 106\end{array}$ & $\begin{array}{l}1 \\
1 \\
1\end{array}$ & $\begin{array}{l}\text { 1B } \\
1 \mathrm{~B} \\
\text { 1B }\end{array}$ & $\begin{array}{l}\text { Esterase } \mathrm{E}_{3} \text { at } M_{F} 59 \\
\text { Esterase } \mathrm{E}_{5} \text { at } M_{F} 22 \\
\text { Acid phosphatase at pI } 8.5\end{array}$ \\
\hline $\begin{array}{r}9 \\
10 \\
11\end{array}$ & $\begin{array}{ll}\text { CNY } & 373 \\
\text { CNY } & 336 \\
\text { CNY } & 211\end{array}$ & $\begin{array}{l}2 \\
2 \\
2\end{array}$ & $\begin{array}{l}2 \\
2 \\
2\end{array}$ & $\begin{array}{l}\text { Esterase } \mathrm{E}_{2} \text { at } M_{F} 63 \\
\text { Esterase } \mathrm{E}_{7} \text { at } M_{F} 16 \\
\text { Esterase } \mathrm{E}_{\alpha \mathrm{a}} \text { undetected }\end{array}$ \\
\hline $\begin{array}{l}12 \\
13\end{array}$ & $\begin{array}{lr}\text { CNY } & 39 \\
\text { CNY } & 8928\end{array}$ & $\begin{array}{l}3 \\
3\end{array}$ & $\begin{array}{l}3 \\
3\end{array}$ & $\begin{array}{l}\text { Esterase } \mathrm{E}_{\alpha \mathrm{a}} \text { at } M_{F} 69 \\
\text { Esterase } \mathrm{E}_{\alpha \mathrm{b}} \text { at } M_{F} 69\end{array}$ \\
\hline $\begin{array}{l}14 \\
15\end{array}$ & $\begin{array}{lr}\text { CNY } & 9018 \\
\text { CNY } & 374\end{array}$ & $\begin{array}{l}4 \\
4\end{array}$ & $\begin{array}{l}4 \\
4\end{array}$ & $\begin{array}{l}\text { Esterase } \mathrm{E}_{6} \text { at } M_{F}-21 \\
\mathrm{GDH} \text { at } M_{F} 16\end{array}$ \\
\hline 16 & CNY 1 & 5 & 5 & $\begin{array}{l}\text { Esterase } \mathrm{E}_{6} \text { at } M_{F}-21 \\
\text { and } M_{F}-5\end{array}$ \\
\hline 17 & CNY 3662 & 5 & 5 & GDH at $M_{F} 17$ \\
\hline
\end{tabular}


Table 1-continued

\begin{tabular}{|c|c|c|c|}
\hline $\begin{array}{l}\text { Laboratory } \\
\text { code }\end{array}$ & $\begin{array}{c}\text { Strain } \\
\text { designation* }\end{array}$ & Zymotype $\ddagger$ & $\begin{array}{l}\text { Main enzyme } \\
\text { electrophoretic } \\
\text { results of the } \\
\text { intraspecies } \\
\text { characterization } \\
\text { correlating } \\
\text { with the RFLP data }\end{array}$ \\
\hline \multicolumn{4}{|c|}{ Yersinia pseudotuberculosis } \\
\hline 1 & CNY 2555 & & Esterase $\mathrm{P}_{4}$ undetected \\
\hline 2 & CNY 2549 & & Esterase $\mathrm{P}_{\alpha \mathrm{a}}$ undetected \\
\hline 3 & CNY 1830 & & Esterase $\mathbf{P}_{\alpha \mathrm{a}}$ undetected \\
\hline 4 & CNY 2463 & & Esterase $\mathrm{P}_{4}$ undetected \\
\hline 5 & CNY 2550 & & - \\
\hline 6 & CNY 2556 & & - \\
\hline 7 & CNY 2553 & & Esterase $\mathrm{P}_{2}$ at $M_{F} 65$ \\
\hline 8 & CNY 1553 & & Esterase $\mathrm{P}_{1}$ at $M_{F} 82$ \\
\hline 9 & CNY 1554 & & Esterase $\mathrm{P}_{1}$ at $M_{F} 82$ \\
\hline \multicolumn{4}{|c|}{ Yersinia intermedia } \\
\hline 1 & CNY 6030 & & Esterase $\mathrm{E}_{\alpha \mathrm{a}}$ at $M_{F} 75$ \\
\hline 2 & CNY 6151 & & Esterase $\mathrm{E}_{\alpha \mathrm{a}}$ at $M_{F} 75$ \\
\hline 3 & CNY 8877 & & Esterase $\mathrm{E}_{\alpha \mathrm{a}}$ at $M_{F} 76$ \\
\hline 4 & CNY 8301 & & Esterase $E_{\alpha a}$ undetected \\
\hline 5 & CNY 8771 & & Esterase $\mathrm{E}_{\alpha \mathrm{a}}$ at $\boldsymbol{M}_{F} 77$ \\
\hline 6 & CNY 5630 & & Esterase $\mathrm{E}_{\alpha \mathrm{a}}$ at $M_{F} 77$ \\
\hline 7 & CNY 6300 & & Esterase $\mathrm{E}_{\alpha \mathrm{a}}$ at $M_{F} 77$ \\
\hline 8 & CNY 6194 & & Esterase $\mathrm{E}_{\alpha \mathrm{a}}$ at $M_{F} 77$ \\
\hline 9 & CNY 6237 & & Esterase $\mathrm{E}_{\alpha a}$ undetected \\
\hline 10 & CNY 5983 & & Acid phosphatase at pI 8.8 \\
\hline \multicolumn{4}{|c|}{ Yersinia aldovae } \\
\hline 1 & CNY 7927 & & Esterase $\mathrm{E}_{1}$ at $M_{F} 78$ \\
\hline 2 & CNY 7928 & & Esterase $\mathrm{E}_{1}$ at $M_{F} 79$ \\
\hline 3 & CNY 6005 & & Esterase $\mathrm{E}_{\alpha \mathrm{a}}$ undetected \\
\hline 4 & CNY 8286 & & Esterase $\mathrm{E}_{\alpha \mathrm{a}}$ at $M_{F} 78$ \\
\hline 5 & CNY 7090 & & Esterase $\mathrm{E}_{\alpha \mathrm{a}}$ at $\boldsymbol{M}_{\boldsymbol{F}} 78$ \\
\hline 6 & CNY 8285 & & Esterase $E_{\alpha \mathrm{a}}$ at $M_{F} 78$ \\
\hline 7 & CNY 7109 & & Esterase $\mathrm{E}_{\alpha \mathrm{a}}$ at $M_{F} 78$ \\
\hline 8 & CNY 8290 & & Esterase $\mathrm{E}_{\alpha \mathrm{a}}$ at $M_{F} 78$ \\
\hline 9 & CNY 7112 & & Esterase $\mathrm{E}_{\alpha \mathrm{a}}$ at $M_{F} 78$ \\
\hline 10 & CNY 8287 & & Esterase $\mathrm{E}_{\alpha \mathrm{a}}$ at $M_{F} 78$ \\
\hline 11 & CNY 7970 & & Esterase $\mathrm{E}_{\alpha \mathrm{a}}$ at $M_{F}>78$ \\
\hline 12 & CNY 7618 & & Esterase $\mathrm{E}_{\alpha \mathrm{a}}$ at $M_{F}>78$ \\
\hline 13 & CNY 7622 & & Esterase $\mathrm{E}_{\alpha \mathrm{a}}$ at $M_{F}>78$ \\
\hline 14 & CNY 7971 & & Esterase $\mathrm{E}_{\alpha \mathrm{a}}$ at $M_{F}>78$ \\
\hline 15 & CNY 7632 & & Esterase $\mathrm{E}_{\alpha \mathrm{a}}$ at $M_{F}>78$ \\
\hline 16 & CNY 7898 & & Esterase $\mathrm{E}_{\alpha \mathrm{a}}$ at $M_{\mathrm{F}}>78$ \\
\hline \multicolumn{4}{|c|}{ Yersinia frederiksenii } \\
\hline 1 & CNY 5975 & $\mathrm{~F}_{1}$ & \multirow{10}{*}{$\begin{array}{l}\text { Presence of esterase } \mathrm{E}_{\beta \mathrm{R}} \\
\text { Presence of esterase } \mathrm{E}_{\alpha \mathrm{c}} \\
\text { GDH at } M_{F} 17 \\
\text { Acid phosphatase at pI } 9.5 \\
\text { or pI } 9.45\end{array}$} \\
\hline 2 & CNY 5960 & $F_{1}$ & \\
\hline 3 & CNY 8721 & $F_{1}$ & \\
\hline 4 & CNY 8684 & $F_{1}$ & \\
\hline 5 & CNY 5966 & $F_{1}$ & \\
\hline 6 & CNY 5981 & $F_{1}$ & \\
\hline 7 & CNY 5982 & $F_{1}$ & \\
\hline 8 & CNY 6334 & $F_{1}$ & \\
\hline 9 & CNY 6150 & $\mathbf{F}_{1}$ & \\
\hline 10 & CNY 8718 & $F_{1}$ & \\
\hline 11 & CNY 6175 & $F_{2}$ & Esterase $\mathrm{E}_{1}$ at $M_{F} 87$ \\
\hline 12 & CNY 8801 & $\mathrm{~F}_{2}$ & GDH at $M_{F} 16$ \\
\hline 13 & CNY 8797 & $F_{2}$ & Acid phosphatase at pI 8.8 \\
\hline 14 & CNY 5976 & $\mathrm{~F}_{3}$ & Acid phosphatase at pI 9.3 \\
\hline 15 & CNY 867 & $F_{4}$ & GDH at $M_{F} 14$ \\
\hline 16 & CNY 8824 & $\mathrm{~F}_{5}$ & Presence of esterase $E_{A I}^{\prime}$ \\
\hline 17 & CNY 8826 & $F_{5}$ & GDH at $M_{F} 19$ \\
\hline 18 & CNY 8849 & $F_{5}$ & \\
\hline $\begin{array}{l}19 \\
20\end{array}$ & $\begin{array}{l}\text { CNY } 8786 \\
\text { CNY } 8787\end{array}$ & $\begin{array}{l}\mathbf{F}_{6} \\
\mathbf{F}_{6}\end{array}$ & $\begin{array}{l}\text { Presence of esterase } \mathrm{E}_{\mathrm{AB}}^{\prime} \\
\mathrm{GDH} \text { at } M_{F} 18\end{array}$ \\
\hline
\end{tabular}


Table 1-continued

\begin{tabular}{|c|c|c|c|}
\hline $\begin{array}{l}\text { Laboratory } \\
\text { code }\end{array}$ & $\begin{array}{c}\text { Strain } \\
\text { designation* }\end{array}$ & Zymotype & $\begin{array}{l}\text { Main enzyme } \\
\text { electrophoretic } \\
\text { results of the } \\
\text { intraspecies } \\
\text { characterization } \\
\text { correlating } \\
\text { with the RFLP data }\end{array}$ \\
\hline \multicolumn{4}{|c|}{ Yersinia kristensenii } \\
\hline 1 & CNY 103 & & \multirow{18}{*}{$\begin{array}{l}\text { Esterase } \mathrm{E}_{2}^{\prime} \text { at } M_{F} 63 \\
\text { Esterase } \mathrm{E}_{2}^{\prime} \text { at } M_{F} 70, \\
\text { Esterase } \mathrm{E}_{\alpha \mathrm{a}} \text { at } M_{F} 79 \\
\text { Esterase } \mathrm{E}_{2}^{\prime} \text { at } M_{F} 70, \\
\text { Esterase } \mathrm{E}_{\alpha \mathrm{a}} \text { at } M_{F} 79 \\
\text { Esterase } \mathrm{E}_{2}^{\prime} \text { at } M_{F} 68, \\
\text { Esterase } \mathrm{E}_{\alpha \mathrm{a}} \text { at } M_{F} 79 \\
\text { Esterase } \mathrm{E}_{2}^{\prime} \text { at } M_{F} 68, \\
\text { Esterase } \mathrm{E}_{\alpha \mathrm{a}} \text { at } M_{F} 79 \\
\text { Esterase } \mathrm{E}_{2}^{\prime} \text { at } M_{F} 68 \\
\text { Esterase } \mathrm{E}_{2}^{\prime} \text { at } M_{F} 70 \\
\text { Esterase } \mathrm{E}_{\alpha \mathrm{a}}^{\prime} \text { at } M_{F} 68, \\
\text { Esterase } \mathrm{E}_{\alpha \mathrm{B}}^{\prime} \\
\text { Esterase } \mathrm{E}_{\alpha \mathrm{a}}^{\prime} \text { at } M_{F} 68, \\
\text { Esterase } \mathrm{E}_{\mathrm{AB}}^{\prime} \\
\text { Esterase } \mathrm{E}_{\alpha \mathrm{a}}^{\prime} \text { at } M_{F} 68, \\
\text { Esterase } \mathrm{E}_{\mathrm{AB}}^{\prime} \\
\text { Esterase } \mathrm{E}_{\alpha \mathrm{a}} \text { at } M_{F} 68 \\
\text { Esterase } \mathrm{E}_{\alpha \mathrm{a}} \text { at } M_{F} 77 \\
\text { Esterase } \mathrm{E}_{\alpha \mathrm{a}} \text { at } M_{F} 77 \\
\text { Esterase } \mathrm{E}_{\alpha \mathrm{a}} \text { at } M_{F} 77 \\
\text { MDH at } M_{F} 36 \\
\text { MDH at } M_{F} 36 \\
\text { MDH at } M_{F} 36\end{array}$} \\
\hline 2 & CNY 490 & & \\
\hline 3 & CNY 8680 & & \\
\hline 4 & CNY 8346 & & \\
\hline 5 & CNY 6048 & & \\
\hline 6 & CNY 8782 & & \\
\hline 7 & CNY 3605 & & \\
\hline 8 & CNY 5553 & & \\
\hline 9 & CNY 5520 & & \\
\hline 10 & CNY 8711 & & \\
\hline 11 & CNY 8347 & & \\
\hline 12 & CNY 5894 & & \\
\hline 13 & CNY 1475 & & \\
\hline 14 & CNY 5874 & & \\
\hline 15 & CNY 5878 & & \\
\hline 16 & CNY 105 & & \\
\hline 17 & CNY 1474 & & \\
\hline 18 & CNY 5591 & & \\
\hline
\end{tabular}

* CNY, Collection du Centre National et Centre Collaborateur OMS pour les Yersinia (Professor H. H. Mollaret), Institut Pasteur, Paris, France.

$\dagger$ According to the biotyping scheme of Bercovier et al. (1980).

$\ddagger$ Zymotype as in Goullet \& Picard $(1984,1988)$.

\section{Results and Discussion}

A representative RFLP pattern obtained for different species of Yersinia is shown in Fig. 1.

\section{Y. enterocolitica}

Seventeen strains belonging to biotypes 1 to 5 were analysed for their rDNA polymorphism by the RFLP pattern for HindIII (Fig. 2a) and EcoRI (Fig. 2b) restriction enzymes. Two distinct riboclasses encompassing the same strains were identified with each enzyme. The strains falling within riboclass 1 belong to biotype 1 ; all the others of riboclass 2 belong to biotypes 2 to 5 . Thus, the RFLP data demonstrate unequivocally that the $Y$. entercolitica species can be divided into two major genetic groups: the strains of riboclass 1 corresponding to biotype 1 and a distinct group of riboclass 2 strains encompassing all the genetically related biotypes 2 to 5 .
The zymotype study supported a similar conclusion: it distinguished the strains of biotype 1 from those of biotypes 2 to 5 both by the presence of esterase bands $E_{3}$ and $E_{5}$ and by the distinct mobility of esterases $E_{2}, E_{4}$ and $E_{6}$ (Table 1) (Goullet \& Picard, 1984). Further differences in the RFLP patterns of both restriction enzymes within riboclass 1 (essentially with fragments of high molecular size) allow its subdivision into ribosubclasses $1 \mathrm{a}$ and $1 \mathrm{~b}$. These ribosubclasses correspond to the subdivision of biotype 1 strains into zymotypes $1 \mathrm{~A}$ and 1B (Table 1), which was based on the electrophoretic polymorphism of acid phosphatase and esterase bands $E_{3}$ and $E_{5}$. Within zymotypes $1 A$ and $1 B$, strains CNY 10389 and CNY 106 (lanes 5 and 8, respectively) are distinguished from the other strains by their characteristic esterase $E_{1}$ polymorphism (Goullet \& Picard, 1984), as they are here by their particular RFLP pattern. The differences in the EcoRI RFLP patterns of the strains in riboclass 2 (biotypes 2 to 5 ) indicates that 


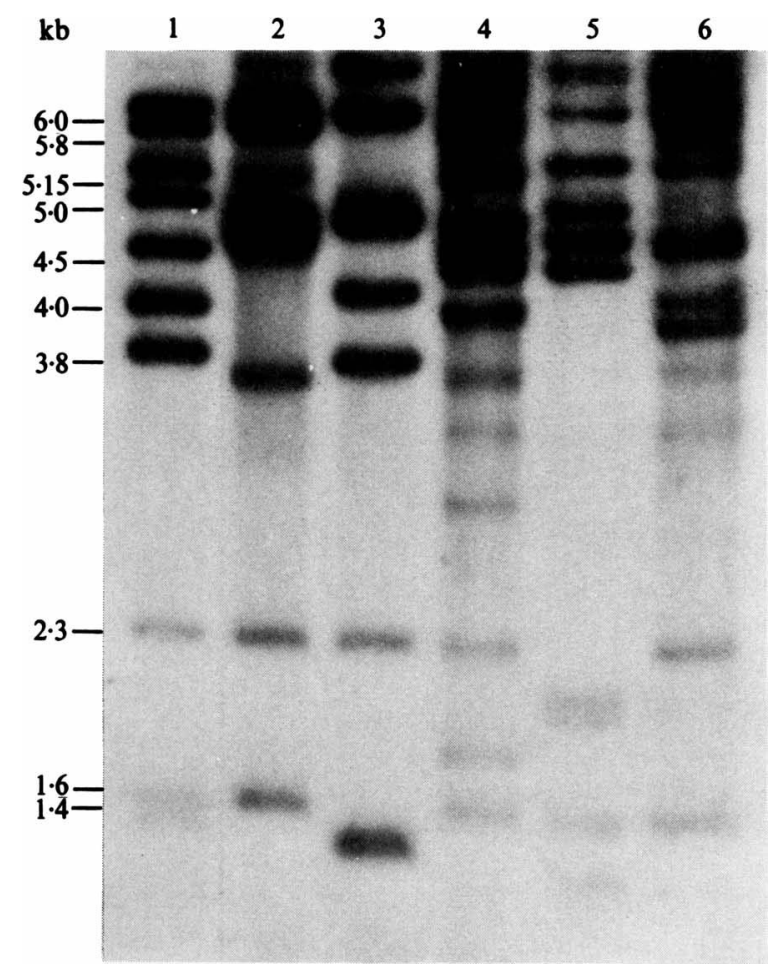

Fig. 1. A representative RFLP pattern obtained for different species of Yersinia: Y. frederiksenii strain CNY 5981 (lane 1); Y. enterocolitica strain CNY 161 (lane 2); Y. pseudotuberculosis CNY 2555 (lane 3); Y. aldovae strain CNY 8287 (lane 4); Y. intermedia CNY 8877 (lane 5); and $Y$. kristensenii strain CNY 8782 (lane 6). A fragment of $2.3 \mathrm{~kb}$ is common to all of the Yersinia species except $Y$. intermedia (see text for discussion).

they fall into two subclasses, $2 \mathrm{a}$ and $2 \mathrm{~b}$, although the HindIII data indicate no such subdivision. The strains of zymotype 2 (biotype 2) are of class $2 \mathrm{a}$ and those of zymotypes 4 and 5 (biotypes 4 and 5) are class of $2 b$. One of the two zymotype 3 (biotype 3) strains (lane 12) fell within riboclass $2 a$ while the other (lane 13) was included in riboclass $2 \mathrm{~b}$. A retrospective examination of the enzyme electrophoretic data indicates that the former strain resembled the zymotype 2 strains as judged by the mobility of esterase $E_{2}$ and the latter resembled zymotypes 4 and 5 in possessing esterase $E_{\alpha b}$. The strains of zymotype 5 are distinguished from zymotype 4 only by the absence of a $3.2 \mathrm{~kb} E c o$ RI fragment and a $6 \mathrm{~kb}$ HindIII fragment; all the other fragments were identical. Zymotypes 4 and 5 were differentiated only on the basis of mobility of glutamate dehydrogenase (CDH). Thus the RFLP data suggest that the strains of biotypes 4 and 5 are closely related, as previously indicated by the similarity of their esterase electrophoretic patterns (Goullet \& Picard, 1984). In addition, two fragments of $2.3 \mathrm{~kb}$ and $1.4 \mathrm{~kb}$ were common to all the EcoRI digests of $Y$. enterocolitica (Fig. 1).

\section{Y. pseudotuberculosis}

Five ribotypes of the nine strains studied were distinguished by their HindIII patterns (Fig. $3 a$ ) and four were distinguished by their EcoRI patterns (Fig. $3 \mathrm{~b}$ ). Most of these patterns correlated with the previously described esterase electrophoretic types. The exception was strain CNY 2556 (lane 6), which was indistinguishable from strain CNY 2550 (lane 5) by esterase electrophoretic data. The converse was found for strain CNY 1830 (lane 3) and strain CNY 2463 (lane 4) which have distinct esterase electrophoretic patterns. Strains CNY 2553 (lane 7), CNY 1553 (lane 8) and CNY 1554 (lane 9), which were differentiated from the other $Y$.pseudotuberculosis strains by the mobilities of esterases $\mathrm{P}_{2}$ for strain CNY 2553 and $P_{1}$ for strains CNY 1553 and CNY 1554, were clearly distinguished by the two restriction enzymes.

$Y$. pseudotuberculosis strains gave a $2.3 \mathrm{~kb}$ fragment in EcoRI digests as did the $Y$. enterocolitica strains, but could be distinguished from all other Yersinia strains by the presence of a $1.1 \mathrm{~kb}$ fragment (Fig. 1).

\section{$Y$. intermedia}

All but one of the 10 strains examined fell in the same riboclass with both EcoRI and HindIII (Fig. 4). The exception, strain CNY 5983 (lane 10), showed considerable differences. It was previously distinguished from the others by the $\mathrm{pI}$ of its acid phosphatase (Table 1). RFLP data suggest that the species $Y$. intermedia is homogeneous. Similar conclusions were reached from a comparison of enzyme electrophoretic data (genetic diversity) with the DNA melting profiles at $60^{\circ} \mathrm{C}$ (Goullet \& Picard, 1988). After EcoRI digestion all strains gave three low molecular size fragments; the $2.3 \mathrm{~kb}$ fragment seen in the other Yersinia species was not detected in $Y$. intermedia, but strains of the latter had a $1.4 \mathrm{~kb}$ fragment in common with Y. enterocolitica (Fig. 1).

\section{$Y$, aldovae}

The HindIII RFLP patterns placed all the strains in a single major riboclass (Fig. $5 a$ ), which agrees perfectly with the monomorphism of GDH and malate dehydrogenase (MDH). However three minor classes of patterns can be distinguished, and such a division appears to correlate with the different esterase electrophoretic types observed (Table 1). For example, strains CNY 7927 and CNY 7928 (lanes 1 and 2), which have an esterase $E_{1}$ of $M_{F} 78$ and $M_{F} 79$ constitute a particular ribotype (minor class 1), whereas strains CNY 7970, CNY 7618, CNY 7622, CNY 7971, CNY 7632 and CNY 7898 
(a)

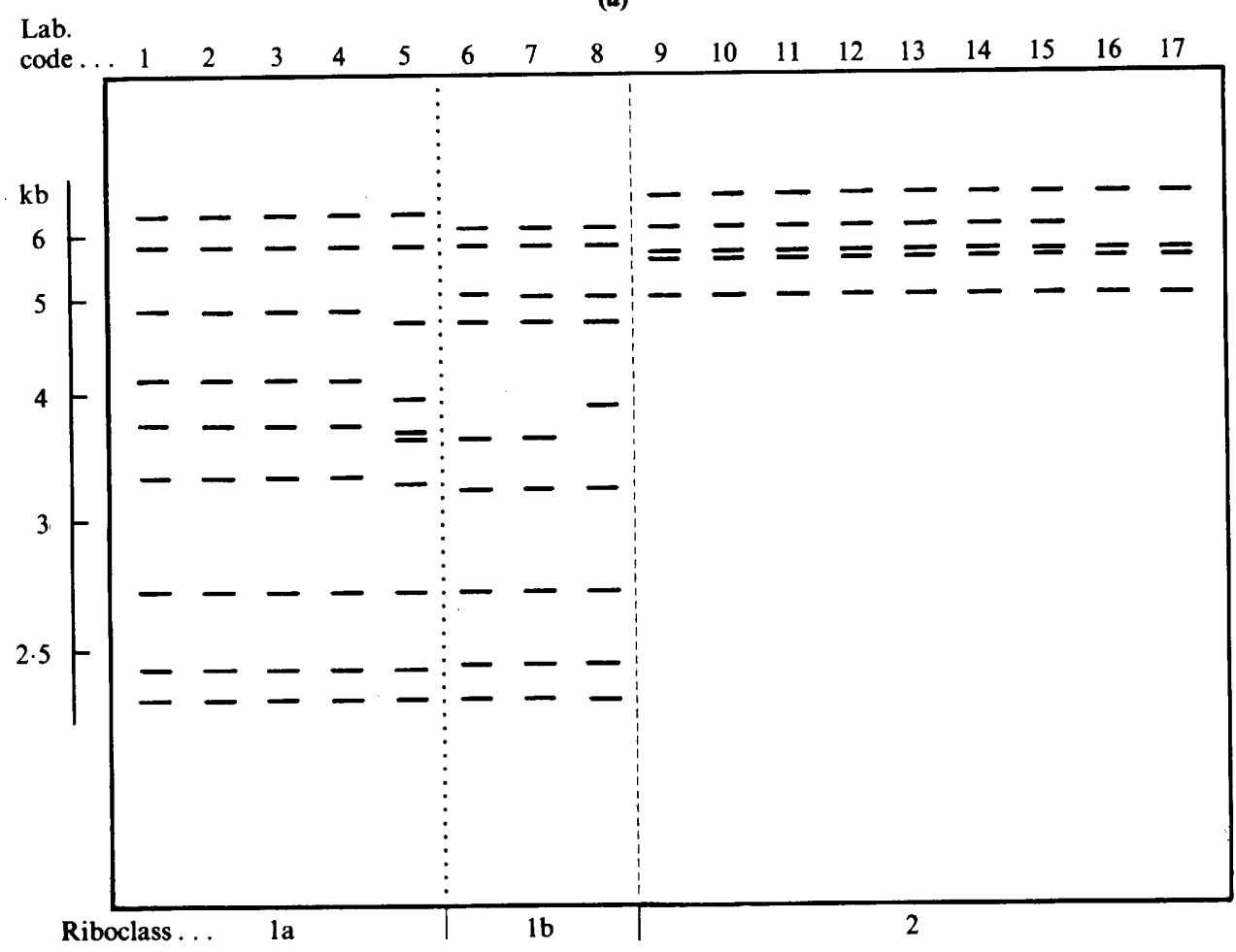

(b)

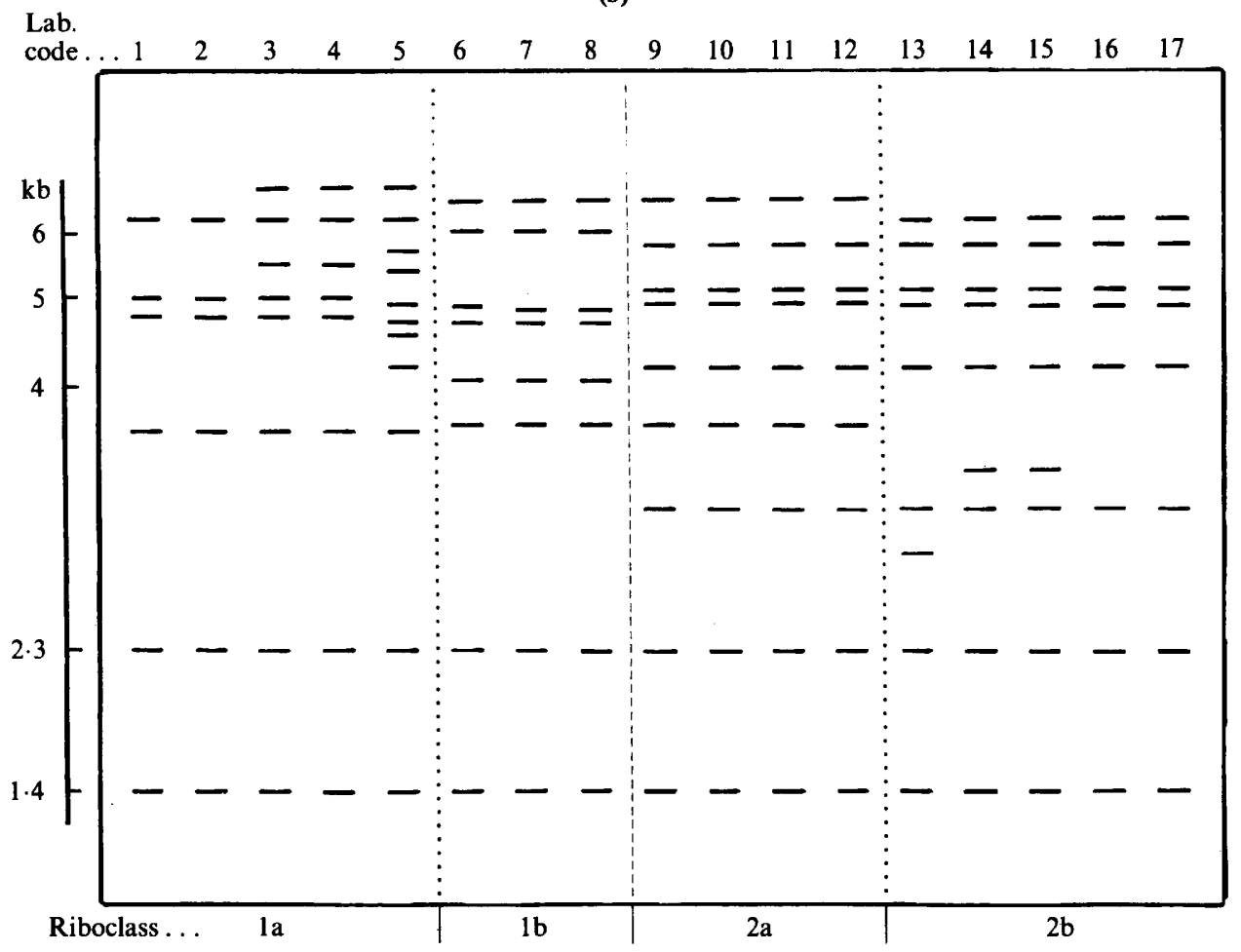

Fig. 2. RFLP rDNA patterns of $Y$. enterocolitica strains. (a) Schematic representation of HindIII restriction pattern and (b) EcoRI restriction pattern of DNA from strains (numbered as in Table 1) after hybridizing to ${ }^{32}$ P-labelled $E$. coli rDNA probe. 

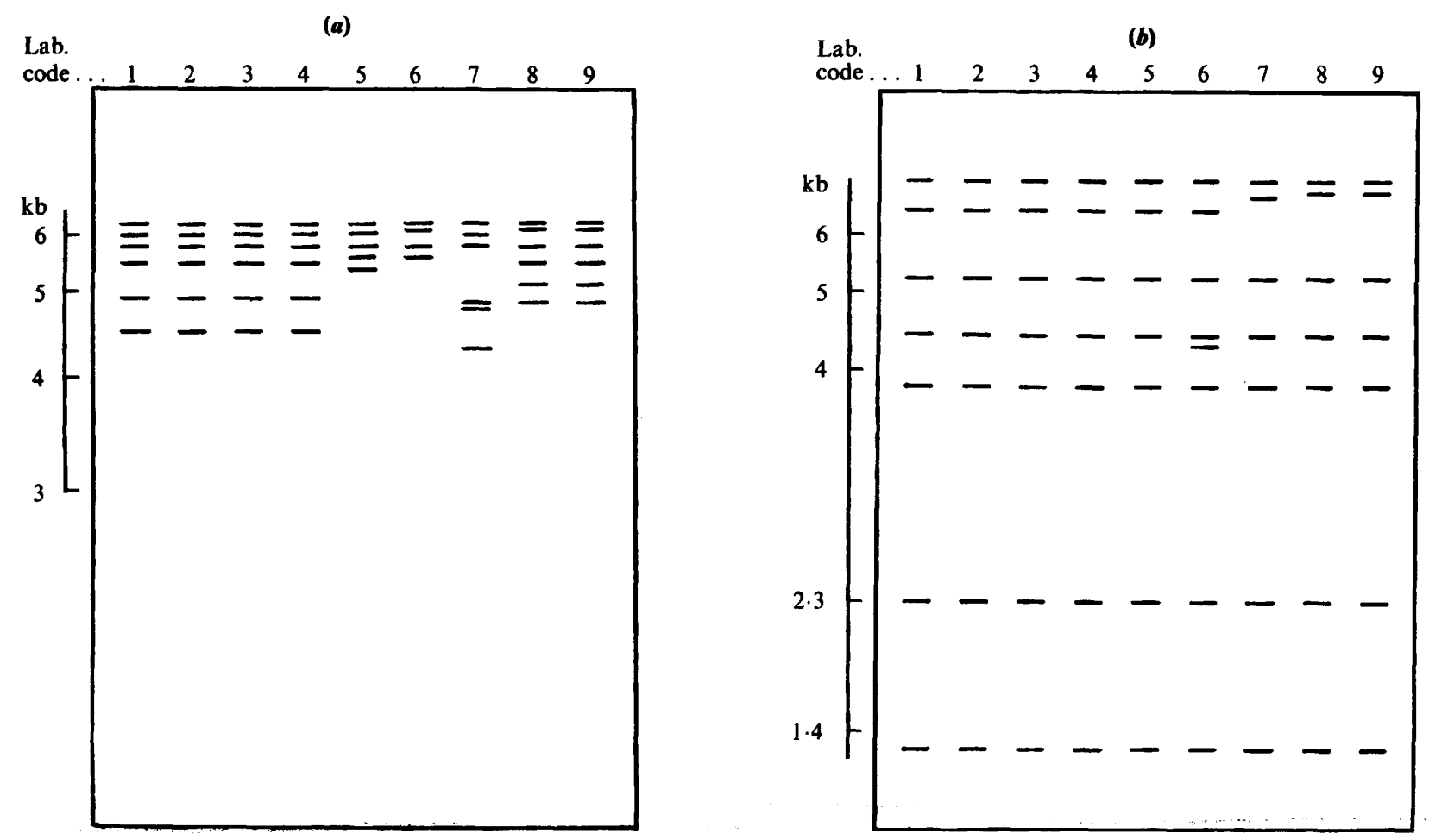

Fig. 3. RFLP rDNA patterns of $Y$. pseudotuberculosis strains. (a), (b), As Fig. 2.
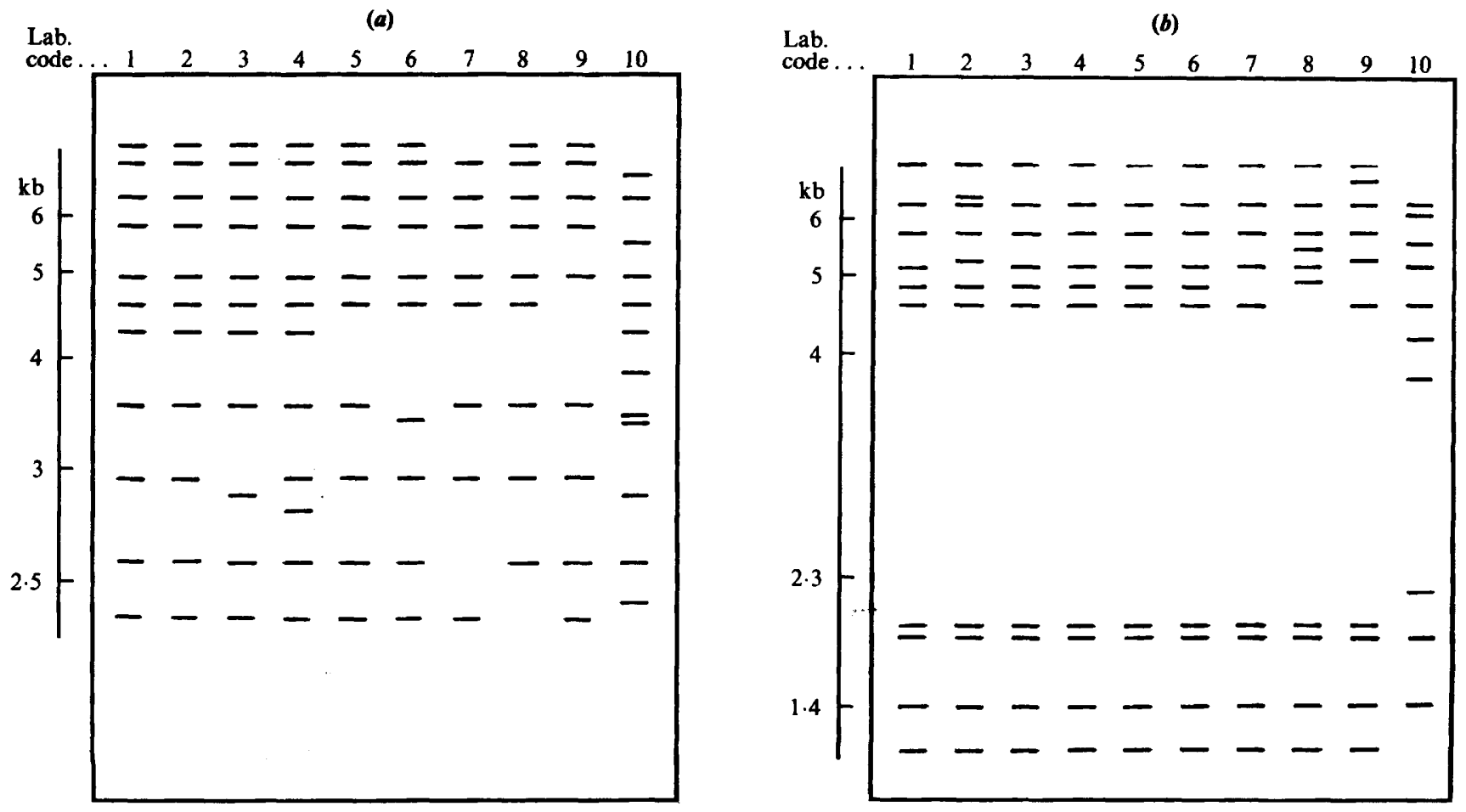

Fig. 4. RFLP rDNA patterns of $Y$. intermedia strains. (a), (b), As Fig. 2. 

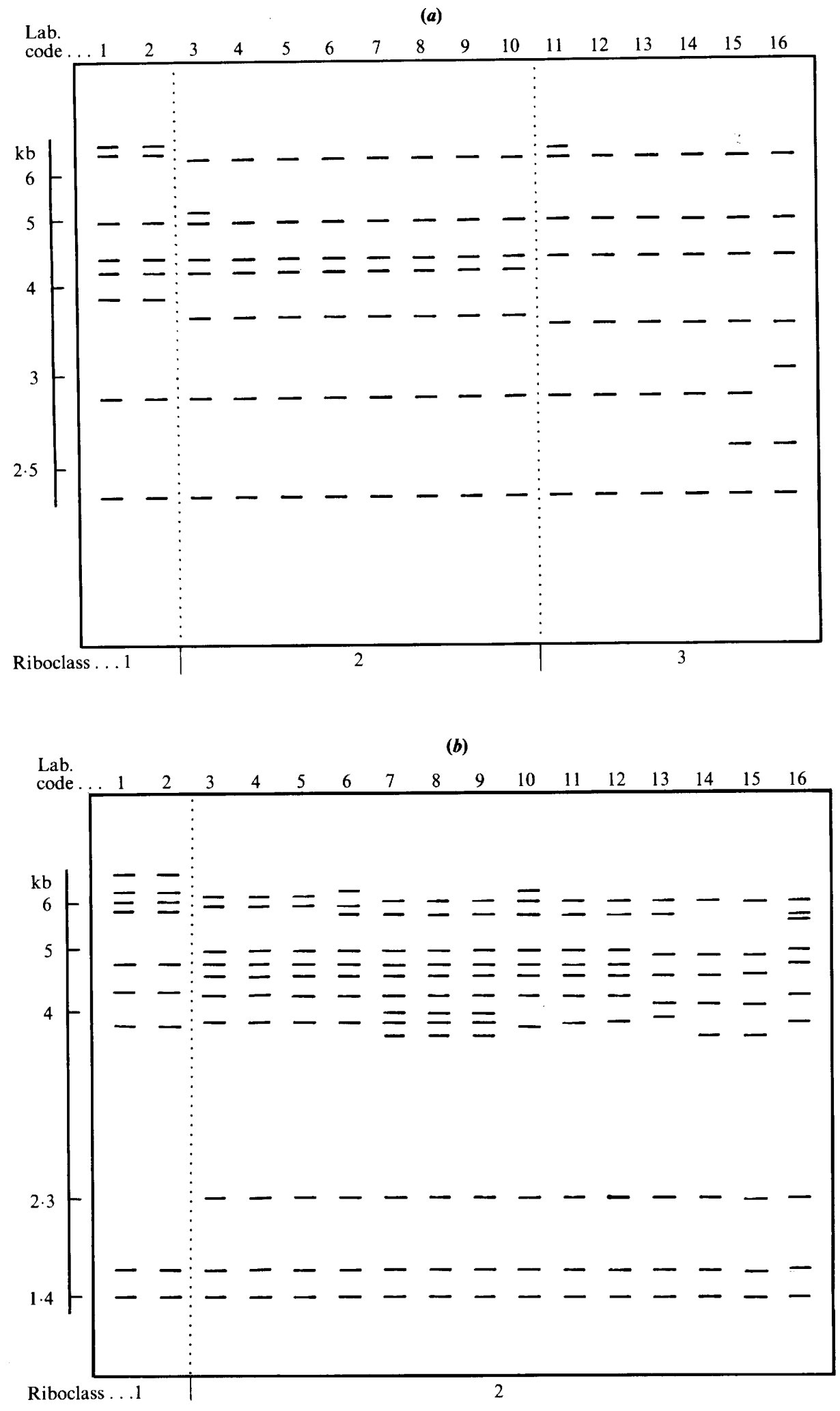

Fig. 5. RFLP rDNA patterns of $Y$, aldovae strains. (a), (b), As Fig. 2. 
(a)
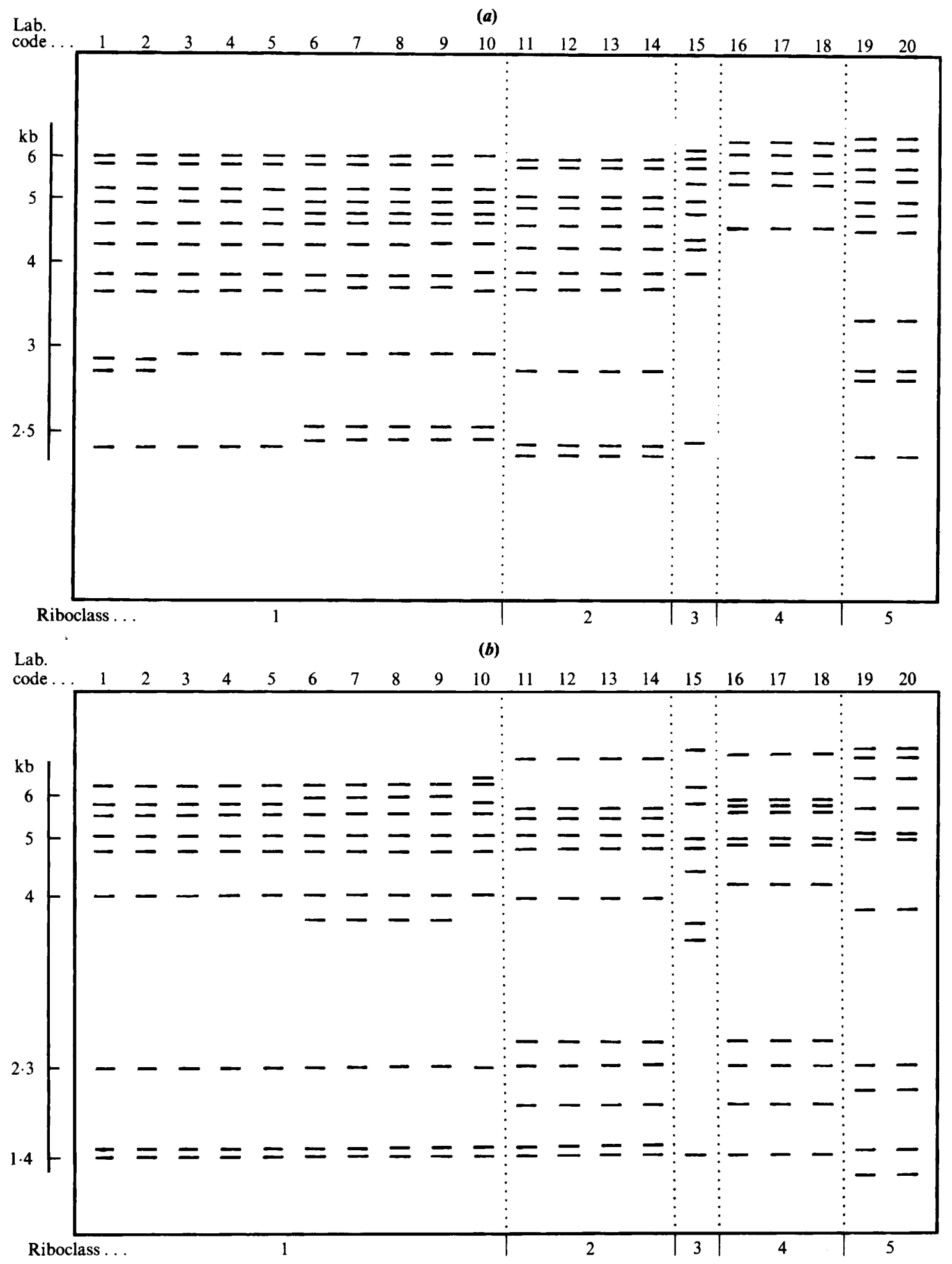

Fig. 6. RFLP rDNA patterns of $Y$. frederiksenii strains. (a), (b), As Fig. 2.

(lanes 11 to 16), whose esterases $\mathrm{E}_{\alpha \mathrm{a}}$ have an $M_{F}>78$, constitute a different minor riboclass (minor class 3 ). The remaining $Y$. aldovae strains have an esterase $\mathrm{E}_{\alpha \mathrm{a}}$ of $M_{F}$ 78 (or no $\mathrm{E}_{\alpha \mathrm{a}}$ was detected) and constitute another group (minor class 2). Only two minor classes were distinguished by EcoRI digestion (Fig. $5 b$ ). Minor class 2 corresponds to the minor classes 2 and 3 defined by HindIII. All strains gave three low molecular size 


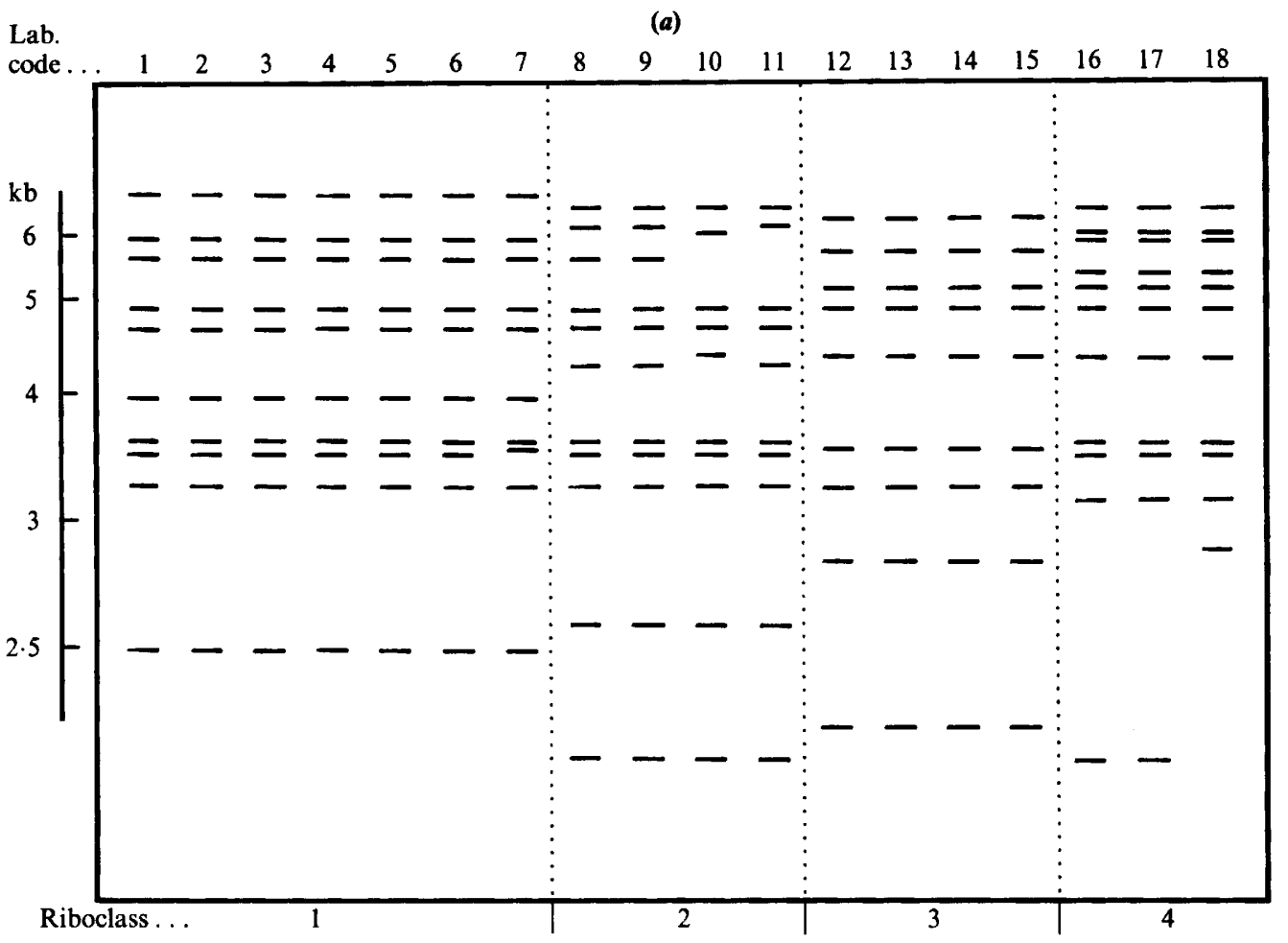

(b)

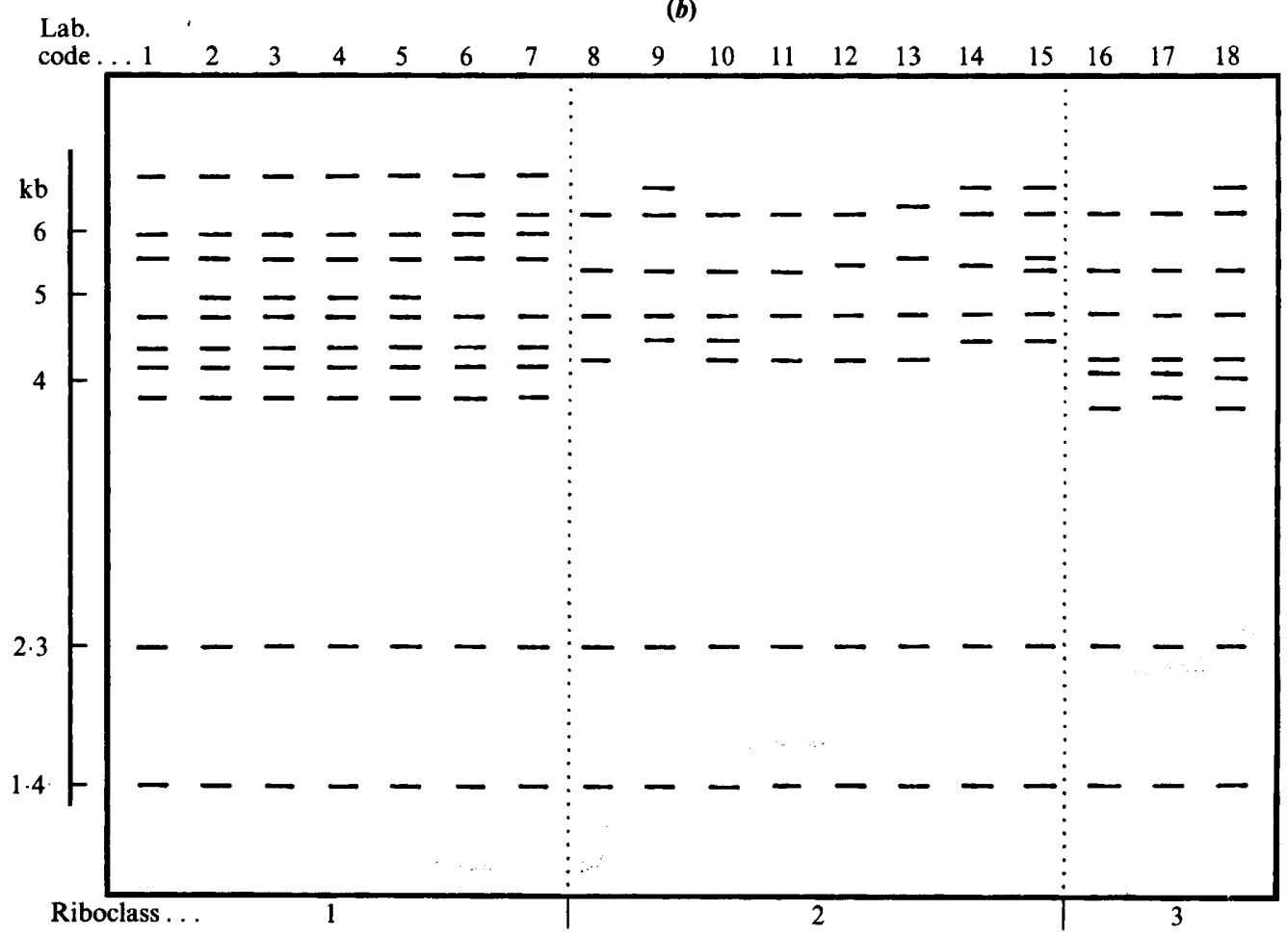

Fig. 7. RFLP rDNA patterns of $Y$. kristensenii strains. (a), (b), As Fig. 2.

fragments (Fig. 1). A $1.4 \mathrm{~kb}$ fragment and a $2.3 \mathrm{~kb}$ fragment were common with $Y$. enterocolitica (except for the strains of the minor class 1 which did not exhibit the $2 \cdot 3 \mathrm{~kb}$ fragment).

\section{Y. frederiksenii}

The rDNA polymorphism revealed by HindIII digestion allowed the strains to be divided into five riboclasses 
(Fig. 6a). An identical subspecies classification was obtained when the EcoRI RFLP was studied (Fig. 6b). The strains of zymotype $F_{1}$ fell within the riboclass 1 group, whereas the RFLP pattern of strains of zymotypes $\mathrm{F}_{2}$ and $\mathrm{F}_{3}$ were indistinguishable using either EcoRI or HindIII. The strains of zymotypes 4, 5 and 6 gave clearly different hybridization patterns with both restriction enzymes. The results unequivocally demonstrate that the classification of $Y$. frederiksenii strains by RFLP corresponds to that of the zymotypes (Table 1) (Goullet \& Picard, 1988). The only discrepancy was that the $F_{2}$ and $\mathrm{F}_{3}$ zymotypes were indistinguishable in terms of their RFLP and hence can be considered to be closely related. A $2.3 \mathrm{~kb}$ fragment was present in the EcoRI digests of all the strains, except for strain CNY 867 (lane 15, $F_{4}$ zymotype). This particular strain has a relative binding ratio (RBR) at $60{ }^{\circ} \mathrm{C}$ of only $64 \%$ with the reference strain (CNY 6175) belonging to zymotype $\mathrm{F}_{2}$ (Brenner et al., 1980; Ursing et al., 1980). Data on the RBR of the strains of zymotypes $F_{5}$ and $F_{6}$, which were clearly distinct from those of zymotypes $F_{1}$ to $F_{3}$ in this RFLP study, are not available. The RFLP and enzyme electrophoresis data suggest that the zymotype $F_{5}$ and $F_{6}$ strains, like strain CNY 867, constitute a distinct group within the species. Similar comparisons were made by Denny et al. (1988) for two pathovars of Pseudomonas syringae using selected cosmid clones of $P$. syringae pathovar tomato DNA as an anonymous probe in the RFLP study.

\section{Y. kristensenii}

The strains could be divided into four riboclasses on the basis of the HindIII RFLP data (Fig. 7a). The correlation with the previous enzyme electrophoretic typing (Table 1) indicates that the strains of riboclass 1 (lanes 1 to 7) have esterase $\mathrm{E}_{2}^{\prime} M_{F}$ values from 63 to 70 and esterase $\mathrm{E}_{\alpha \mathrm{a}} \boldsymbol{M}_{F}$ values of 79 . The strains of riboclass 2 (lanes 8 to 11) were characterized by an $\mathrm{E}_{\alpha \mathrm{a}}^{\prime}$ esterase $M_{F}$ 68 and/or the presence of an esterase band similar to esterase $\mathrm{E}_{\mathrm{AB}}$. The strains of riboclass 4 (lanes 16 to 18 ), which exhibit a very distinct RFLP pattern, were phenotypically distinguished by a MDH $M_{F}$ value of 36 . Thus, as for the strains of zymotypes $\mathrm{F}_{5}$ and $\mathrm{F}_{6}$ of $Y$. frederiksenii, the electrophoretic variation of the $\mathrm{MDH}$, which exhibits a little polymorphism, corresponds to a major intraspecies differentiation. Three riboclasses of RFLP were identified by EcoRI digestion (Fig. $7 b$ ). Riboclasses 1 and 3 were identical to HindIII riboclasses 1 and 4 whereas riboclass 2 corresponded to the strains of class 2 and 3 defined by HindIII digestion. This suggests that the strains of HindIII-defined classes 2 and 3 are closely related. All $Y$. kristensenii strains exhibited two common fragments of $2.3 \mathrm{~kb}$ and $1.4 \mathrm{~kb}$ with EcoRI digestion, which were also observed in most strains belonging to $Y$. enterocolitica, $Y$. aldovae and $Y$. frederiksenii (Fig. 1).

\section{Conclusions}

An explanation of the correlation of enzyme electrophoretic polymorphism with rDNA polymorphism observed in the strains of the six Yersinia species could be based on the fact that rDNA sequences exist in several copies which are interspersed among single copy sequences of the bacterial DNA. Consequently, we hypothesize that the polymorphism of the rDNA sequences reflects the evolution of the single copy sequences.

\section{References}

Allardet-Servent, A., Bourg, G., Ramuz, M., Pages, M., Bellis, M. \& RoIzes, G. (1988). DNA polymorphism in strains of the genus Brucella. Journal of Bacteriology 170, 4603-4607.

Bercovier, H., Kafri, O. \& Sela, S. (1986). Mycobacteria possess a surprisingly small number of ribosomal RNA genes in relation to the size of their genome. Biochemical and Biophysical Research Communications 136, 1136-1141.

Brenner, D. J., Ursing, J., Bercovier, H., Steigerwalt, A. G., Fanning, G. R., Carter, G. P. \& Mollaret, H. H. (1980). Deoxyribonucleic acid relatedness in Yersinia enterocolitica and Yersinia enterocolitica-like organisms. Current Microbiology 4, 195200.

Denny, T. P., Gilmour, M. N. \& Selander, R. K. (1988). Genetic diversity and relationships of two pathovars of Pseudomonas syringae. Journal of General Microbiology 134, 1949-1960.

Goullet, PH. \& Picard, B. (1984). Distinctive electrophoretic and isoelectric focusing patterns of esterases from Yersinia enterocolitica and Yersinia pseudotuberculosis. Journal of General Microbiology 130, $1471-1480$

Goullet, Ph. \& PiCARD, B. (1988). Characterization of Yersinia enterocolitica, $Y$. intermedia, $Y$. aldovae, $Y$. frederiksenii, $Y$. kristensenii and $Y$. pseudotuberculosis by electrophoretic polymorphism of acid phosphatase, esterases, and glutamate and malate dehydrogenases. Journal of General Microbiology 134, 317-325.

GrIMONT, F. \& GRIMONT, P. A. D. (1986). Ribosomal ribonucleic acid gene restriction patterns as potential taxonomic tools. Annales de l'Institut Pasteur/Microbiologie 137B, 165-175.

Irino, K., Grimont, F., Casan, I., Grimont, P. A. D. \& THE Brazilian Purpuric Fever Study Group (1988). rRNA gene restriction patterns of Haemophilus influenzae biogroup aegyptius strains associated with Brazilian purpuric fever. Journal of Clinical Microbiology 26, 1535-1538.

Kakoyiannis, C. K., Winter, P. J. \& Marshall, R. B. (1984). Identification of Campylobacter coli isolates from animals and humans by bacterial restriction endonuclease DNA analysis. Applied and Environmental Microbiology 48, 545-549.

Kristiansen, B. E., Sorensen, B., SPanNe, O. \& Bjorvatn, B. (1985). Restriction fingerprinting and serology in a small outbreak of B15 meningococcal disease among Norwegian soldiers. Scandinavian Journal of Infectious Diseases 17, 19-24.

KuIJPER, E. J., VAN AlPhen, L., LeENDERS, E. \& ZANEN, H. C. (1989) Typing of Aeromonas strains by DNA restriction endonuclease analysis and polyacrylamide gel electrophoresis of cell envelopes. Journal of Clinical Microbiology 27, 1280-1285.

McClenaghan, M., Herring, A. J. \& Aitken, I. D. (1984). Comparison of Chlamydia psittaci isolates by DNA restriction endonuclease analysis. Infection and Immunity 45, 384-389. 
Magee, B. B., D'Souza, T. M. \& Magee, P. T. (1987). Strain and species identification by restriction fragment length polymorphisms in the ribosomal DNA repeat of Candida species. Journal of Bacteriology 169, 1639-1643.

Marshall, R. B., Winter, P. J. \& Yanagawa, Y. (1984). Restriction endonuclease DNA analysis of Leptospira interrogans serovars icterohaemorrhagiae and hebdomadis. Journal of Clinical Microbiology 20, 808-810.

Patterson, T. F., Patterson, J. E., Masecar, B. L., Barden, G. E. HIERHOLZER, W. J. \& ZeRvos, M. J. (1988). A nosocomial outbreak of Branhamella catarrhalis confirmed by restriction endonuclease analysis. Journal of Infectious Diseases 157, 996-1001.

Picard-Pasquier, N., Ouaghed, M., Picard, B., Goullet, Ph. \& KRISHNAMOORTHY, R. (1989). A simple, sensitive method of analyzing bacterial ribosomal DNA polymorphism. Electrophoresis 10, 186-189.

SchWARTZ, D. C. \& CANTOR, C. R. (1984). Separation of yeast chromosome-sized DNAs by pulsed field gradient gel electrophoresis. Cell 37, 67-75.
SOUTHERN, E. M. (1975). Detection of specific sequences among DNA fragments separated by gel electrophoresis. Journal of Molecular Biology 98, 503-517.

Stull, T. L., LiPUMA, J. J. \& Edlind, T. D. (1988). A broad-spectrum probe for molecular epidemiology of bacteria: ribosomal RNA. Journal of Infectious Diseases 157, 280-286.

Ursing, J., Brenner, D. J., Bercovier, H., FanNing, R., Steigerwalt, A. G., Brault, J. \& Mollaret, H. H. (1980). Yersinia frederiksenii: a new species of Enterobacteriaceae composed of rhamnose-positive strains (formerly called atypical Yersinia enterocolitica or Yersinia enterocolitica-like). Current Microbiology 4, 213-217.

Yogev, D., Halachmi, D., KenNY, G. E. \& Razin, S. (1988). Distinction of species and strains of mycoplasmas (mollicutes) by genomic DNA fingerprints with an rRNA gene probe. Journal of Clinical Microbiology 26, 1198-1201. 